\title{
Evaluating the Case for Greater Use of Private Prosecutions in England and Wales for Fraud Offences
}

\begin{abstract}
This paper considers the challenges and opportunities that exist in England and Wales for the use of private prosecutions for Fraud. It considers the need for sanctions against fraudsters: looks at the prosecution landscape as it has evolved, especially during the 21st century: considers the legal basis for private prosecution and gives a brief history of its extent. The advantages and disadvantages associated with private prosecution are considered and recommendations made on the changes needed before there could be significant developments in the use of private prosecutions.
\end{abstract}

Key Words: Fraud, Sanctions, Private prosecution, Fraudsters

\section{Introduction}

This paper sets out to identify reforms to help fill the 'sanctions gap' in countering fraud. Special attention is paid to the role that private prosecutions could play in 'punishing' fraudsters. Results in this paper are taken from commissioned research (Button et al, 2012), involving a literature search from the UK and USA, 44 interviews in both public and private sectors and a questionnaire survey of around 400 members of the counter fraud community.

\section{Fraud, Sanctions and Punishment}

Fraud is an extremely diverse problem encompassing a very wide range of acts (Doig, 2006). What unites them all is that they involve crimes that '... use deception as a principal modus operandi' (Wells, 1997.) Fraud is a major problem to society (Levi et al, 2007), which the National Fraud Authority suggests cost the UK $f 73$ billion during 2011 (National Fraud Authority, 2011). This has doubled from 2010 although this will not represent the totality of losses to fraud. The KPMG fraud barometer also shows a substantial increase in fraud losses from just under $£ 1.5$ billion in 2010 to over $£ 3.5$ billion in 2011 (KPMG, 2012) and research based upon fraud loss measurement exercises has further suggested fraud (and error) losses on average are $5.7 \%$ of measured expenditure in organisations (Gee et al, 2010; 2011). Therefore, fraud costs public bodies, private organisations and individuals and affects services and causes emotional distress (Button et al, 2009)

Like other criminals, fraudsters, are punished for different reasons (Newburn, 2007):

- to discourage the individual or others from offending again (individual/general deterrence)

- To ensure the offender does not profit from his crime (restitution, compensation, redress)

- To protect society from the person reoffending (incapacitation).

- To reinforce social values and bonds

- To punish the offender (retribution).

The importance of punishment and deterring fraudsters has recently increased with the passing of national legislation e.g., Fraud Act 2006 (Home Office, 2006) and Bribery Act, 2010 (Home Office, 2010). While the most important aspect of deterrence is the perception of the chances of getting caught (Farrington et al, 1986) the severity of the penalty is not as important (Newburn, 2007). The evidence base, however, is thin for fraudsters but studies confirm similar conclusions (Klepper and Nagin, 1979; Hollinger and Clark, 1983 Gill, 2007). This, we suggest, is largely because the public resources to investigate and then prosecute crime are currently insufficient. 
When dealing with fraud there can be wider sanctions beyond the criminal justice system which can be very severe. Unfortunately such tools are not used to their full potential. The most significant research has argued that a wide range of sanctions should be used, extending beyond the criminal. The most effective means of ensuring compliance is to pursue a gradual escalation of sanctions beginning with persuasion and warnings and rising to licence revocation (Ayres and Braithwaite, 1995) (see Figure 1 below). The most important lesson for fraud is that there should be a wide range of sanctions available to use, with a gradual escalation to the most serious sanction available. However, many organisations do not use the full range of the pyramid. This paper therefore identifies reforms to help fill the 'sanctions gap' in countering fraud.

\section{Figure 1: Regulatory Enforcement}

Pyramid

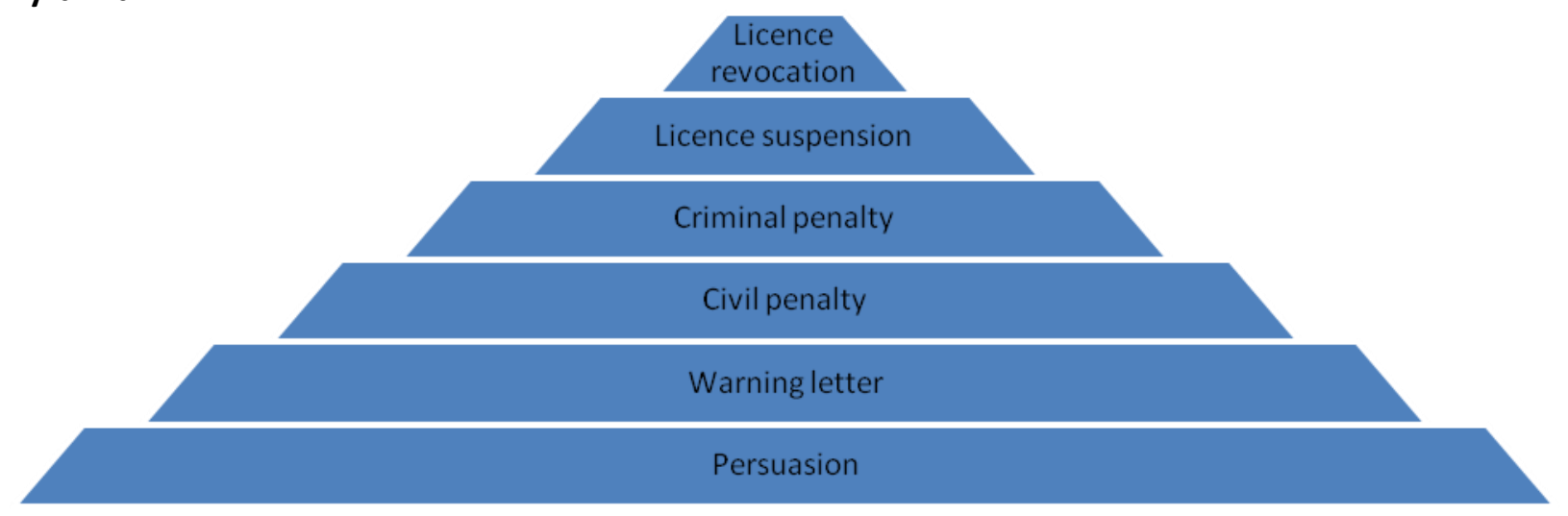

3. Prosecution landscape: investigators, prosecutors and the state

3.1 Fraud Investigation

Fraud Investigations are carried out by a number of organisations/staff with varying skills and aims (Brooks et al, 2008). Since the 1980s the number of specialist fraud police officers has declined substantially (Doig et al, 2001; Doig, 2006; Button et al, 2007). The police are not the largest investigative body, but they are the most important. This is because of their gatekeeper role into the criminal justice system and powers of arrest, search and access to information. There are many consequences of the reduction of police resources put into investigating fraud: these include: a very small proportion of frauds are actually reported to the criminal justice system, even fewer result in a sanction being applied (our research estimates about $0.4 \%$ ), delays and justice failure, the 'decriminalisation of fraud' where resources do not allow any action, differential justice concerning fraud, including a postcode and wealth lottery and no real deterrence from the justice system

The resource and 'skills' gap of the police to cope with fraud is not new (Brooks and Button, 2012). The inability of the police to satisfy the demand for their services has led in some sectors to industry actually funding specialist units. These are

- The Dedicated Cheque and Plastic Crime Unit (2002), of London police officers to investigate card and cheque fraud, particularly by organised gangs, which is funded by the banking industry 
- Police Vehicle Fraud Unit (2007) The Police Vehicle Fraud Unit is part of the ACPO Vehicle Intelligence Service and is funded by the Finance and Leasing Association (FLA). Its aim is to recover vehicles secured fraudulently from dealers using false information for finance.

- Insurance Fraud Enforcement Department (2012) tackles insurance fraud. It is based in the COLP and is funded by the Association of British Insurers.

There are also a number of specialised police forces with constabulary powers who effectively serve either a government department and/or private company. Some of these also have a fraud investigation capacity too. The more important of these are:

Ministry of Defence Police (MoD and MoD contractors);

British Transport Police (Rail companies);

Civil Nuclear Constabulary (nuclear power stations);

Various Ports Police

Mersey Tunnels Police; and

Various Parks Police

What all these illustrate is that there is a precedent for police officers with full constabulary powers to work for private and public organisations protecting them from crime. At another level some organisations have paid for police officers, usually within a public sector body, such as an NHS Trust or local authority and normally covering a wide range of crimes: as two interviewees noted:

'Other London boroughs have got some police secondees, so they funded the police to provide a detective to sit within their teams. And obviously, there's probably more cases that end up with the CPS via the police officer there' (London Borough CFS).

'until last year we paid for a police officer to sit in my fraud team office, so he was our link in to the police and prosecution service. We had to do away with that because it was a question of I've got to reduce my budget, I either have to get rid of a police officer or I have to get rid of an investigator' (Transport Authority Security Manager).

The investigation of fraud then is very expensive and cost becomes an issue. However, in some cases private companies fill the gap by contributing towards the costs of investigation. In January 2012 it was revealed that the Metropolitan Police had received a payment from Virgin Media to cover overtime to collect evidence from receiver boxes. Furthermore, in some sectors the Employer Supported Policing scheme is used; this scheme allows staff to become special constables: e.g., at Gun Wharf Quays, Portsmouth the Loss Prevention Manager and some of the security guards are also special constables. Some days they patrol the facility as security staff, some as special constables, during which they still get paid by their employer. As cuts in policing continue this models is likely to prove attractive to this and other sectors.

\subsection{The Public Prosecution Landscape in England and Wales}

This is dominated by the Crown Prosecution Service but it is not the only agency. Under the Criminal Justice Act 1987 (Home office, 1987) the Serious Fraud Office was created, to investigate and prosecute serious and complex fraud. In 2010, under the Commissioners for Revenue and Customs Act 2005, the Revenue and Customs Prosecutions Office (RCPO) was created to prosecute cases brought by HMRC and SOCA. The RCPO was itself brought under the CPS by 2011. In addition there is 
a range of other organisations that conduct prosecutions under a common law right specifically retained when the CPS was established. The possibility of the CPS taking over all these prosecutions was considered by the Justice Committee of the House of Commons in 2009 but rejected in favour of more co-ordination between agencies. (Justice Committee, 2012)

Pursuing a criminal prosecution through the CPS is not the only option. There is the option to pursue a private prosecution, which is brought by an individual or organisation not acting for the police or other prosecuting authority. The right was established in Section 6 of the Prosecution of Offences Act 1985:

Prosecutions instituted and conducted otherwise than by the [Crown Prosecution] Service.

(1)Subject to subsection (2) below, nothing in this Part shall preclude any person from instituting any criminal proceedings or conducting any criminal proceedings to which the Director's duty to take over the conduct of proceedings does not apply.

(2)Where criminal proceedings are instituted in circumstances in which the Director is not under a duty to take over their conduct, he may nevertheless do so at any stage.

There is no duty on those pursuing a private prosecution to inform the CPS, but it is does have the power to take over a case. There is extensive guidance for the CPS in this matter, with a specific section on how the CPS should cope with Private prosecutions (CPS, 2012). This deals with how the CPS might discover such a prosecution e.g., when to take it over or to liaise with the organisation conducting it, how to judge whether to continue with the prosecution or to drop it and how to deal with disclosure of information and with appeals. However, no statistics are kept centrally. Broadly speaking the CPS will take over a case if it regards the evidence and the public interest as sufficient and there is a particular need for the CPS to do so. Clearly resources will play a part. The CPS has no interest in fighting cases, which it feels it is definitely going to lose, however persuaded the individual or organisation wanting to bring the prosecution feels convinced of its importance.

There have been high profile private prosecutions which failed, such as the Stephen Lawrence prosecution in 2006, a high profile murder case with a Black teenage victim where evidence at that time was not sufficient for the CPS to prosecute. This may have discouraged all but the most brave individuals or organisations from attempting private prosecutions. However, we have uncovered a small number of organisations which have and continue to undertake private prosecutions and we consider there is value in examining how this number could be increased.

The Royal Society for the Prevention of Cruelty to Animals (RSPCA) is a charity and has no special statutory right to pursue prosecutions. It undertakes a wide range of functions to support animal welfare one of which is the investigation/prosecution of crimes against animals. In their 2010 annual report 1830 cases were reported to their Prosecutions Department involving 2777 people and RSPCA secured 2441 convictions. The process is organised through a separate prosecutions department, which RSPCA inspectors submit their case to. If it meets their evidence and public interest tests, which are similar to the equivalent CPS tests, as well as their animal welfare tests they pursue prosecution. Cases are prosecuted by solicitors located where the case will be heard. RSPCA also has a range of warnings and cautions used prior to commencing prosecution. The RSPCA has assumed a de facto responsibility for the investigation and prosecution of crimes against animals. There is sometimes shared interest with Natural England (a government body which undertakes enforcement on wildlife and the natural environment), but the police and CPS have effectively ceded this area to the RSPCA. The Royal Society for the Protection of Birds (RSPB) also investigates crimes against birds. It, however, has not undertaken a private prosecution since 1992. 
A different sector is that of intellectual property crime. Such crimes could be considered a species of fraud but whatever their classification they are crimes where the private sector has experienced similar problems to fraud such as growing volumes, increased complexity and lack of resources from the police and other enforcement bodies. This results in a variety of bodies being created with investigatory powers and in some cases the capacity for private prosecution:

- Anti-Copying in Design: mediation services, legal advice and accredited scheme for lawyers specialising in this area. http://acid.eu.com/

- $\quad$ Anti-Counterfeiting Group: a trade association focussed against counterfeiting. http://www.a-cg.org/guest/index.php

- $\quad$ BPI (British Recorded Music Industry). a trade association with anti-piracy unit conducting enforcement activities http://www.bpi.co.uk/category/protecting-uk-music.aspx

- Business Software Association. a global trade association with anti-piracy activities. http://www.bsa.org/country/BSA\%20and\%20Members.aspx

- Federation Against Copyright Theft(FACT) a private body funded to investigate copyright theft related to movies and subscription television services. http://www.fact-uk.org.uk/

- Federation Against Software Theft (FAST) a private body funded to deal with software piracy. http://www.fastiis.org/

- The Publishers Association http: a private organisation with an anti-piracy section http://www.publishers.org.uk/

- UK Interactive Entertainment IP Crime Unit carries out_Investigations and enforcement activities related to video games. http://ukie.info/content/ukie-ip-crime-unit

- $\quad$ IFPI an international anti-piracy unit related to music. http://www.ifpi.org/content/section about/services.html

These bodies vary in their capabilities. However, it is worth focussing upon Federation Against Copyright Theft (FACT) - a body with a $\mathrm{f} 4 \mathrm{~m}$ budget and 50 staff funded by the film and media industry which operates very much like a private police force and uses sanctions against those who are found to have breached the law of copyright. Criminal prosecutions form part of their sanctions policy and they do work with local authorities, the police and CPS to take these forward. Sometimes this is not possible and on those occasions they may pursue private prosecutions. Five years ago they conducted dozens of private prosecutions per year but this has declined to a handful in recent years. As the Director general of FACT said:

DVD and online piracy much be recognised as a crime of growing national significance. FACT's aim is to create an effective deterrent to film piracy in the UK by increasing public awareness of this type of crime that can have a destructive influence on local communities

The British Recorded Music Industry (BPI) also has an anti-piracy unit, and like FACT it has pursued private prosecutions, as has the Federation Against Software Theft (FAST) which operates in protecting software from piracy has considered private prosecutions, but not undertaken them, preferring to work with law enforcement. The reasons for this are hard commercial facts:

'the software industry is reluctant to enforce its rights very heavily in the sense that software is simply a tool and if you put your customers off buying your tool they'll go and buy a competitor's tool. And so it's quite reluctant to really use the ultimate sanction of IP law' (Counter Fraud Officer). 
Even the Post Office has also recently reorganised itself to deal with cases through private prosecutions. As a GPO Counter fraud officer made clear:

We have our own legal department that act as a criminal law prosecution authority. ..... we will conduct a private prosecution .... and take it through the court process: And ... we also have authorised and trained financial investigators credited under the Proceeds of Crime Act, who go in, identify, seize and recover assets through the court. And we also do debt recovery as well through the civilian process.

All of these cases illustrate the use of private prosecution process. Below we highlight why people interviewed decided on this process using a succession of vignettes from the commissioned research.

\subsection{The reluctance of Police to take the case}

'We went to the Police and said, look, we want to prosecute, we want to investigate, we want this guy arrested, but we left it very much up to the Police to say, we've looked at the law, all right, and we are prepared to take prosecute this.......So in this particular case, it got to point of charge and it was decided, between CPS and us and the Police, they said, do you know what, we're not going to pursue this, because of the level of complications and the technicality around it. So we said, look, okay, then, we'll take it forward ourselves, and we did, and we won, and we were successful' (Media Services Investigation Manager).

'We dealt with one where there was Merseyside and Lancashire Police dealt with two large groups, $20+$ people eventually arrested, 20 ended up in court in 2 organised groups. For the CPS to try to pull together different forces and three different trading standards would've been very difficult, and I think it would've gone into the too complex band and probably been carved up and failed miserably. So we undertook a criminal prosecution under those circumstances' (Anti-Piracy Unit 3 Head).

'Basically this company used to just fold and another phoenix company set up. And they were supplying jukeboxes providing to pubs and clubs across the North of England, unlicensed...so they're full of music and they told the pubs and clubs, don't worry, we pay the PPL PRS licenses for this, so you've nothing to worry about. So they were undercutting all the legitimate retailers in it, and making millions, I think about $f 8.8 \mathrm{~m}$. And every time they got served with some civil letters, they folded, moved off and set up a new company in a false name. So I said, 'why don't we just go criminally?' It's absolutely a clear criminal case; let's just arrest them for conspiracy to defraud. So again, engaged with local law enforcement, they were arrested for that, convicted at court and also with the Proceeds of Crime, so double whammy. I think he got three years or three and a half years' (Anti-Piracy Unit 3 Head).

\section{Advantages and disadvantages of private prosecutions}

One of the principal reasons individuals or organisations pursue private prosecutions is to trigger police interest with the hope they will take that particular or type of cases more seriously. At one level the prosecution is launched in a campaigning way to secure media interest and expose the lack of interest in the police and/or other bodies. This was the approach of cases brought by the League Against Cruel Sports. One consultant described a case:

'I tried to, and in the end it was taken over by the police. And that was just purely because I was not happy...the police wouldn't act, this was in respect of a particular fraud case in the NHS...despite that .... the police would not act on it. So we said, 'Right okay, I'm going to launch a private prosecution.' Did everything possible to 
achieve that. Once the police realised we were doing it, they then took over the case' (Counter Fraud Consultant).

A further example was one where a company was keen to use private prosecutions to ensure police interest. There had been a concern the police would not be interested because they thought the CPS would not be interested. By guaranteeing that if the CPS said no they would pick up the case for a private prosecution they were able to secure the police interest.

'we went to the Police and we said, look, we want to prosecute but are prepared to take this to criminal (private) prosecution.... So they said okay, well, let's just take it, and they were quite happy, I think, that give them a level of confidence that, you know, even if they initiate it and they couldn't finish it, then we will pick it up' (Media company investigations manager).

A further advantage of pursuing a private prosecution is that it is also possible to recover some costs from the state on completion of the case in court, even if it is not successful: one respondent noted:

'The situation is that a person or organisation bringing a private prosecution can claim costs back from central funds at the end. The rationale is that people should not be dissuaded from taking this course of action because of cost. We generally recover $90 \%$ of our costs. But of course that can take a long time. Also you should get costs back even if you are unsuccessful as long as the case has been properly brought' (Anti-Piracy Unit Director General).

For many organisations, however, the prospect of private prosecutions is too expensive. Clearly the complexity of the case and the level at which it is heard will all influence the cost. As one consultant noted:

'Well, if you go to a magistrate's court then probably the cost wouldn't be that great. And I think you can even represent yourself in a magistrate's court, can't you? So if the investigation was done for you, and you could produce the evidence, individual victims probably could take that forward. If it's a large case, then I think it's quite right that big companies should actually pay money to prosecute cases against them. Why should they have the nationalised industry and the Government subsidising action in respect of losses to their company's budget?'

Other interviewees were more pessimistic about the costs, as one building supplies manager noted:

For us it's back to value again is that the cost of doing that in the majority of cases would far surpass the value of the fraud. It's like civil again..... In the market that we are in and the sort of experiences that we get it just doesn't make a lot of sense on the numbers. Plus that if you are talking to my FD or CEO, he'd be saying, "Hang on a minute. We pay $f 90 \mathrm{M}$ a year in business rates, an element of that goes to the police, and what are they doing for it?" Why should we have to fund private prosecutions?

Evidence from our research illustrated a wide range in costs. The RSPCA managed to pursue prosecutions at a cost of around $£ 3,000$ per case: for BPI and Virgin it was between $£ 80,000$ and $£ 300,000$ per case. For FACT one case alone had cost over $f 1$ million. 
Table 2 Costs of Private Prosecution

\begin{tabular}{|l|l|}
\hline Name of Organisation & Costs \\
\hline RSPCA & $£ 3349$ per defendant per case. \\
\hline FACT & $\begin{array}{l}\text { Historically } £ 10,000 \text { per case, } \\
\text { but recent case over } £ 1 \\
\text { million. }\end{array}$ \\
\hline Virgin & About $£ 300,000$ per case. \\
\hline BPI & About $£ 80,000$ per case. \\
\hline
\end{tabular}

The hostility and reaction of the CPS and/or the police was another factor (also see Brooks et al, 2008). However, there is still the potential for the CPS to take over a case and discontinue it, which is a potent barrier to pursuing a criminal private prosecution. As the Head of Security at a large supermarket chain noted:

'If we've got the evidence and we present it to and seek the assistance of the police to put forward some papers for the CPS, I can never quite see the point of us actually doing it privately, including of course that the CPS has the right to take it over. So no, we don't go down that line'.

However, both CPS interviewees noted the possibility of taking over a case as a real prospect:

'I mean the National Fraud Authority, you know, speak of what they call orphan cases, cases which aren't prosecuted by anybody. And it's theoretically possible isn't it that private prosecutions could be brought by corporate or by representative groups. But again, you see, I mean even there if that was going to happen and they were able to muster sufficient evidence to actually mount a successful prosecution then I think at that stage ordinarily CPS would well actually you know we will prosecute'.

'It would be wrong to say there isn't a place for it, because, the right to bring a private prosecution remains: the test as to whether we will allow a prosecution to continue has changed, recently, it used to be that where there was, effectively, no prima facie case, we would step in, take the proceedings over and discontinue them. Our stance on that has changed, fairly recently, in that, now, if the case that has been started by the private prosecutor doesn't pass our two stage code test, that there's a realistic prospect of conviction and it's in the public interest to prosecute, then, we will take the case over and discontinue and, of course, the code test is a higher test than the prima facie case test and there was some debate, as to whether, if we raise the threshold, for private prosecutions, to the same level as our own code test, whether that, actually, leaves any place for a private prosecutor, at all, because, as you say, if it's good enough for us, then, we should be running it and, if it's not, then, it shouldn't be run at all ... So, it's not easy, it's not going to be easy, I suspect, for private prosecutors to use that right, in practical terms'.

Another interviewee noted that if the CPS and/or police had already rejected the case there was little prospect in pursuing it. 
Yes, I think don't bother. If the police and the CPS are not willing to take it in the public interest then I think you are already on the back foot: you are throwing good money after bad, I just don't see what the good outcome would be for a private criminal prosecution. I would never recommend it'.

Some interviewees were concerned at the quality of some private prosecution cases and that some form of quality control would be required. A private investigator noted:

'Again, why not, why not? I can do that because I can put a reasonably good file together. But you have got to make sure that if you are going down that process, then you have got to make sure that what you do is correct, legal and conforms to the process. That's why you have to have somebody as a prosecutor to monitor what's taking place. So, although I'm saying, yes it could be done, it might be that you need to go through a prosecution review. I think you would find that a lot of cases would be thrown out'

The Philips principle of separation of investigators from prosecutors was a concern for some interviewees, particularly the CPS.

'There are, obviously, different motivations for prosecuting people for cruelty to animals, than there are prosecuting people who have committed fraud.... There is a clear financial incentive on the part of either a large institution or a group that's been underwritten by large financial institutions. So, I think, the real problem would be the lack of independence, the clear motive on the part of the investigator, to get a conviction, which isn't there for the Police and the CPS in the same way. I think, there would always be a fear if any type of offence is being investigated and prosecuted by an individual or a body that has a vested interest in getting a prosecution, that there are inherent dangers, in that'.

The target of the prosecution also has an influence in the likely success. If a private prosecution is pursued it is unlikely the defendant will be remanded in custody, which would be the case with the police and CPS. This means if the defendant is involved in organised crime from another country and there is a high risk they will abscond, the lack of the remand tool is a big weakness. As one interviewee noted:

'...the inherent difficulties of being able to do private criminal prosecutions, where you're dealing with a workforce that is probably illegal in terms of immigration status, certainly transitory...once they're charged, you see, once they are charged they... if they are interned a Court warrant can be issued for their arrest. Now, whether you are ever going to find them, that's another matter, but you have... you can keep them in custody if they have no fixed abode, so they have all sorts of powers once they are charged. If we are going to deal with it they will be bailed from the police station. They will be given an address, even with the immigration authorities involved. We will never see them again'.

\section{Assessment of private prosecution}

Private prosecution provides a means to rebalance the opportunities for prosecution between the public and private sectors. The state has many more options if it wants to pursue a criminal prosecution, but for the private sector they are stuck - in most cases - with the CPS. Private 
prosecution has the potential to be abused, but with appropriate safeguards enabling the private sector to pursue private prosecution more easily to close the gap and relieve the state of some pressures and enhances the criminal sanctions against fraudsters. Enhancing the capacity for companies to pursue this and providing adequate safeguards are clearly essential.

Even if Police input to fraud investigation and prosecution were enhanced, which is unlikely in current economic circumstances, there would still be a substantial gap in meeting the demand for criminal prosecution. There is also the issue that for many victims of fraud, - particularly in the private sector - there is currently only one realistic option to pursue a criminal prosecution. Although the CPS input is free at the point of service, realistically, at the current moment: limited CPS resources mean that services are rationed; many, perhaps most, victims do not get the level of service they want; and there is limited opportunity for competition or alternative provision. As one interviewee was to comment:

'I think the police force is the last nationalised industry, one of the last nationalised industries we've got in this country, where everything is done for you and you have very little control over it. And I would like to see an element of competition brought into this area, or choice, so that if the police can't handle something it's easier for individuals, if they are victims, to access other sources of the skills needed to investigate what's happened to them, and a private prosecution'.

Many individuals and organisations pay taxes and expect when they become victims a particular level of service. In many fraud cases at the moment the police and the CPS in some areas of the country are unable to provide that service. This paper has highlighted examples of private prosecutions which have occurred. In the commercial world these have been rare. There is nothing to stop individuals or companies pursuing private prosecutions now.

However, it would be sensible to ensure the risks of abuse and standards of the public sector are maintained. That the private sector also has stronger guarantees cases will not be taken over to be discontinued. There are also financial implications, given some of the costs can be claimed back. Therefore the CPS should publicise the measures currently available to enable an organisation to become a prosecuting authority and where organisations wish to pursue a private prosecution, but it is not recognised, the measures they must pursue to ensure it is not taken over by the CPS and discontinued. This requires that organisations should more actively consider the option of a private prosecution for fraud.

It also requires that the CPS should outline and publicise a process for organisations to become a prosecuting authority as well as set out clearly the requirements for those not recognised to conduct a private prosecution such that it would not be taken over to discontinue. A further option would be for a sector or sectors to come together to fund a body with a remit to investigate and sanction fraudsters. There would also be a case for the Government to provide some funding to such a body. A relatively small injection of money from the Government of a few million pounds could help to kick-start such a body. It could also be funded from member subscriptions and/or charging for services. Such a body could also undertake other functions which will be discussed later. There are also likely to be reduced costs for the CPS in not having to examine so many cases which they might take over or discontinue.

A variation on this could be a more commercial partnership or partnerships offering a one stop shop of consultancy, investigation and sanctions services. Changes to legislation regarding the provision of professional services also make it possible for one organisation to offer a one stop shop of investigation, accounting and legal services. The basic functions of what such bodies could like are set out below. A central function of such a body or bodies would be to focus on some of the cases in the SME sector and publicise them when complete. 


\section{A federation against fraud}

This could be funded by members and charging for services (possibly on an insurance model). It could be linked to fraud forums and other relevant bodies: publicise the fight against fraud: offer triage and investigative services: offer legal sanctions services including prosecution: offer training services: and accreditation services for counter fraud services providers in: consultancy, investigation, accountancy, legal etc. Our research has highlighted that what many organisations would like when they have a suspected fraud is for a person with the knowledge of all possible options/sanctions to do an immediate assessment and offer independent advice of the options available.

It was shown earlier the system that has emerged is one where the state in some sectors has access to special investigatory and prosecution mechanisms to bypass the limited resources of the CPS and police. Such options should also be open to the private sector to pursue. This is already happening in some areas and there is nothing in law to stop organisations pursuing this. However, to protect and regulate this area it would seem timely for the CPS to bring forward a scheme of accreditation and/or a code practice for such private prosecutors.

This would result in the following actions:

- The counter fraud community should look to establish a central body to counter fraud which engages in investigations and the pursuit of sanctions.

- More commercial providers should consider offering private prosecutions as part of their services along with traditional investigation and civil services.

\section{Conclusion}

The system of justice that existed before 1829 was described as (Johnston, 1992) :

'...having little or no attempt at criminal detection. Crime was brought to the courts when victims prosecuted offenders. Officials did not go out to find it. Justices dealt with the evidence, but detection and apprehension was left to the victims, who often went to great lengths to regain stolen property...'

We feel that there are parallels in the above statement to the treatment of fraud at the start of the $21^{\text {st }}$ century. A fair assessment of the processing of fraud in 2012 would be:

- a varied commitment to bringing fraud before the criminal courts amongst victims:

- many frauds do not go near the criminal justice system, either through choice or resources available:

- the pursuit of fraudsters is shifting from the state towards the victims (or agents) to organise:

- a focus upon getting money back over justice.

The current economic climate is a powerful factor against the creation of a stronger police anti-fraud resource today. However, the problem of fraud continues to grow and in the absence of more state intervention, it is becoming more and more necessary for the private sector to become more involved in investigation and prosecution. This paper has demonstrated that the state and the 
private sector need to work together to create new institutions to react effectively to the growth in fraud.

\section{Acknowledgement}

This paper is based on work carried out by the Centre for Counter Fraud Studies at the University of Portsmouth for the Midlands Fraud Forum, Eversheds and PKF : Button et al (2012)

\section{References}

Ayers, I., and Braithwaite, J., 1995. Responsive Regulation. Oxford: Oxford University Press.

Brooks, G., Button, M., and Frimpong, K., 2008. Policing fraud in the private sector: a survey of the FTSE 100 companies in the UK, International Journal of Police Science and Management, 11(4), 493+ Brooks, G., and Button, M. 2012. The Police and Fraud Investigation and the case for a National Solution in the United Kingdom. The Police Journal. 84, 305-319

Button, M., Johnston, L., Frimpong, K., and Smith, G., 2007. New directions in policing fraud: The emergence of the counter fraud specialist in the United Kingdom. International Journal of the Sociology of law, 35 (4), 192-208

Button, M., Lewis, C. and Tapley, J. 2009. A Better Deal for Victims. London: National Fraud Authority Button, M., Lewis, C. Shepherd, D., Brooks, G., and Wakefield, A. 2012. Fraud and Punishment: Enhancing Deterrence Through more Effective Sanctions: Centre for Counter Fraud Studies, University of Portsmouth.

CPS, 2012 Private prosecutions:

http://www.cps.gov.uk/legal/p to r/private prosecutions/index.html. (Accessed 18/10/2012)

Doig, A., Johnson, S., and Levi, M., 2001. 'New Public management, Old Populism and the Policing of Fraud', Public Policy and Administration 16: 91-111

Doig, A., 2006. Fraud. Cullumpton: Willan Publishing

Farrington, D., P., Ohlin, L., E., Wilson, J., Q. 1986. Understanding and Controlling Crime. New York: Springer Verlag;

Casey, J., T. and Sholz, J., T. 1991. Beyond Deterrence: Behavioral Decision Theory and Tax Compliance. Law and Society Review, 25, 821-844.

Gee, J., Button, M., and Bassett, P., 2010. Fraud Loss Measurement: a short guide to the methodology and approach. PKF: London

Gee, J., Button, M., and Brooks, G., (2011) The Financial Cost of Fraud. What the data from around the world shows. London: PKF/CCFS.

Gill, M., 2007. Learning from Fraudsters; Reinforcing the message. Perpetutity: Leicester

Hollinger, R. and Clark, J., (1983) Deterrence in the workplace: perceived certainty, perceived severity and employee theft. Social Forces, 62, 398-418

Home Office. 1987.

Johnston, L. 1992. The Rebirth of Private Policing. Taylor and Francis: London

Justice Committee, House of Commons (2012) The CPS: Gatekeeper of the Criminal Justice System, http://www.publications.parliament.uk/pa/cm200809/cmselect/cmjust/186/186.pdf ( Accessed 24 /09/2012)

Klepper, S., and Nagin, D., 1989. Tax Compliance and Perceptions of the Risks of Detection and Criminal Prosecution. Law and Society Review, 23, 209-40.

KPMG., 2012.

http://www.kpmg.com/uk/en/issuesandinsights/articlespublications/newsreleases/pages/fraudbarometer-boom-time-for-fraudsters-as-austerity-bites.aspx ( Accessed 24/09/2012)

Levi, M., Borrows, J., Fleming, H., and Hopkins, M., 2007. The Nature, Extent and Economic Impact of Fraud in the UK. ACPO: London 
National Fraud Authority, Annual Fraud Indicator:

http://www.homeoffice.gov.uk/publications/agencies-public-bodies/nfa/annual-fraud-

indicator/annual-fraud-indicator-2012?view=Binary (Accessed 24/09/2012)

Newburn, T., 2007. Criminology. Cullompton: Willan

Wells, J.,T. 1997. Occupational Fraud and Abuse. Obsidian: Dexter, Michigan 